\title{
The use of biotechnologies in textile processing and environmental sustainability: An emerging market context
}

In the

\section{Technological Forecasting and Social Change}

(ISSN: 0040-1625)

By

\author{
Mahfuzur Rahman \\ Lincoln International Business School \\ University of Lincoln, UK \\ Md Morsaline Billah \\ Biotechnology and Genetic Engineering Discipline \\ Khulna University, Bangladesh
}

\author{
Dieu Hack-Polay \\ Lincoln International Business School \\ University of Lincoln, UK
}

Ashraful Alam

Salford Business School

University of Salford, UK 


\title{
The use of biotechnologies in textile processing and environmental sustainability: An emerging market context
}

\begin{abstract}
The research aims to critically discuss key new biotechnologies in textile processing and examines the foundation of the resistance to adoption of such technologies in emerging markets. Using semi-structured interviews and the scientific literature, the paper draws on experts' opinions about enzyme applications; at the same time, the paper interrogates policymakers and economic operators about the barriers to biotechnology adoption in emerging markets. The paper finds that the application of biotechnologies in textile processing is an environmentally sustainable alternative to traditional chemical processing. Enzymatic processing involves less water and energy, thus causing less environmental degradation. The research builds on strategic management tools, such as Lewin force field analysis and change framework to examine drivers and barriers to enzymatic processing specifically in the textile sector in developing economies. This has enabled the paper to suggest more vigorous and systematic actions from both policymakers and economic actors for greater environmental sustainability. The research contributes to raise awareness about the environmental consequences of older textile processing methods and defuses the argument that new technologies are out of reach for emerging market economic actors. Biotechnologies in the form of enzymatic processing represent strategic opportunities for emerging markets in economic, environmental and public health terms.
\end{abstract}

Keywords: Technological forecasting; textile; enzyme; environmental sustainability; biotechnology 


\section{Introduction}

There is an emerging environmental awareness and social concern about the health and wellbeing of communities near textile plants. This is due to increasing evidence of harmful chemicals used in textile processing which endanger public health and environmental livelihood (Chatha et al., 2017; Yusuf et al., 2017; Nimkar, 2018). In the light of these concerns, there is a growing push for greener methods in the textile sector, particularly with biotechnology (Gwozdz et al., 2017). Biotechnological advances increasingly offer fresh perspectives for sustainability in the manufacturing sector (Petruzzelli et al., 2015; Coccia, 2017; Deng et al., 2019; Stucki and Woerter, 2019). In the early years of biotechnological development, it was visualised that biotechnological innovations would contribute immensely to solving the global challenges related to agricultural productivity, disease management, climate change and environmental management. Biotechnology was considered as an enabling tool which would make significant contribution by provisioning a number of applications including better healthcare, enhanced food security through sustainable agricultural practices, supply of safe drinking water, improved and efficient industrial processes, sustainable afforestation and reforestation practices and environment protection by detoxifying hazardous wastes (UNEP, 1992; Konde, 2009). Since then, the global biotechnology industry has experienced an exponential growth in different sectors.

In the textile sector, which is a significantly polluting industrial sector in many emerging markets in Asia, bioprocessing presents numerous opportunities to reduce the sector's environmental footprint. Using enzymes and various biological agents has been successful in producing goods and services in different contexts (OECD, 2001; Jørgensen et al., 2006). In the developing economy context, there is a mounting desire and vision to expand industrial development to bring about sustained economic growth (Adomako et al., 2013; Danso et al., 2019). However, there is also increasing awareness that waste generated from industrial activities results in environmental deterioration, pollution of air, water and soil, and emits massive amounts of greenhouse gases which are responsible for global climate change. There are calls to reduce further deterioration significantly to prevent an overwhelming burden on the global environment. However, if developing countries follow the same path of industrialisation as developed countries, this goal cannot be achieved easily, and sustainable development would be jeopardised. In most emerging economies, textile and apparel industries are vital to increase the gross domestic product (GDP) and export earnings, while employing millions of people, mostly women. To continue 
business with major clothing brands and meet the increasing pressure of sustainable production processes, suppliers and textile owners need to satisfy international standards for working conditions and environmental impact. Although biotechnology is considered as one of the largest enabling technologies in textile wet preparatory processing (Bigliardi, et al., 2005) to impart better functionalities to textile products and offer environmental protection, existing findings are focused on a western context (the United States and European countries). This indicates that developing countries have already missed the train of biotechnological innovations. Yet, there is a huge potential for biotechnological innovation in the textile sector particularly from a non-western or developing country context (Rahman et al., 2019). However, in the current biotech literature, it has been overlooked and there is a research gap to be addressed in the scenarios applicable to these countries. Therefore, this article aims to examine the extent to which the use of industrial technologies, and particularly enzyme-based processing, can enhance sustainability in the textile sector and safeguard the environment and community livelihoods in non-western economies.

In its current trajectory, the textile sector of many developing countries, such as Bangladesh, will continue to expose people and environments to damaging and hazardous effects (Yusuf et al., 2017; Nimkar, 2018; Rahman et al., 2019). In this study we have explored alternative and sustainable futures with key industry stakeholders by analysing their perceptions regarding introduction of enzyme-based processes in textile industry. The research focus is socio-material anticipatory systems and practices used by the groups in the same but different contexts (Enslev et al., 2018). This study used interviews with textile engineers, manufacturers, biotechnologists, authorities and consumers to forecast particular elements of sustainable futures. Together they interact with biocatalysts, chemicals and textile fibres to make and contest futures and establish ways of dealing with hazards and risks as this network of actors move between groups and contexts (Rahman et al., 2019). This study has developed shared knowledge amongst practitioners in the textile and garment industry with respect to improving environmental impacts and increasing sustainability, specifically focusing on bio-based (enzyme) processing. The research takes an interdisciplinary and inter-professional approach to forecasting alternative futures for the sector to harness a wide range of valid generational and professionally specific knowledge, including expectations of the future. The findings from this study will provide environments for a mix of researchers and professionals to create and study future images for the industry. This study contributes to the existing knowledge in several ways. First, it contributes to the biotechnology 
literature, as it sheds light on the factors that hinder the adoption of these technologies in a nonwestern context. The desire of developing economies to expand industries is likely to have severe repercussions on the environment. As a result, we offer a timely and critical contribution. Second, we offer a qualitative analysis to extend the debate on the use of enzyme biotechnology in the textile industry - based on semi-structured interviews with industry experts. Third, our study applies the Force Field Analysis framework of Lewis (1951) to identify the forces that impede the adoption of biotechnologies in emerging economies. Given that our study finds that there are multiple factors restricting firms from adopting these technologies, this study contributes to the theoretical framework of Lewis (1951).

The literature thus far has concentrated on either raising awareness or new textile technologies or awareness of worsening environmental issues. The literature has not adequately shown how strategic management can effectively bridge these two poles to ensure that 'awareness' is translated into practical implementation of biotechnologies that render the textile industry sustainable because such technologies, at the same time, ensure environmental protection. Our study fills this gap. This study is, to the authors' knowledge, the first to use the force field analysis theory to examine the use of enzyme biotechnology processing in emerging economies, thus integrating strategic management with technology forecasting for environmental sustainability. The remainder of this paper is organised as follows. In the next section, we present a review of background literature on textile enzyme processing and the theoretical framework. Section three introduces the research methodology and discusses the research settings. Section four presents the findings of the study. Finally, section five presents the discussion and conclusion.

\section{Background literature}

There is significant evidence that the implementation of technology in the industrial sector yields substantial benefits and presents strategic opportunities (Verret, 1991; Cooper, 1993; HackPolay et al., 2020). Enzymes, which derive from the activities of active biological organisms, are biological catalysts that perform frequent chemical reactions in moderate atmospheric temperatures, $\mathrm{pH}$ and cell pressure (Rahman et al., 2020). They are characterised by a remarkable efficiency and specificity. Essentially, they are protein in nature and biodegradable (Shen and Smith, 2015). The reaction specificity of the enzymes could be tailored for textile applications

without undesirable effects (Shen, 2009). Commercially available enzymes are obtained from 
plants, microbes and animal tissues. For industrial applications, natural enzymes are not readily available in enough amounts and are largely manufactured by fermentation techniques. Enzymes can be classified into oxidoreductases, transferases, hydrolases, lyases, isomerases and ligases based on the type of catalyzed reaction (Choudhury, 2014).

Scientists see hydrolases as a key class of enzymes in textile wet processing, which catalyses hydrolysis of chemical bonds. The sub-group of hydolases comprises amylases, cellulases, pectinases, catalases and proteases, which are used at various steps in textile processing. However, laccases and peroxidases belonging to the oxidoreductase group are used for decolourising textile effluents, bleaching textiles, fabric surface modification and synthesis of dyes (Shen and Smith, 2015). Table 1 shows the major enzymes for textile applications.

Table 1 Enzymes used in various wet textile preparatory processes

\begin{tabular}{|c|c|c|}
\hline Broader category of Enzymes & Specific Enzymes & Processes \\
\hline \multirow[t]{2}{*}{ Hydrolase } & Amylase & \multirow[t]{2}{*}{ Desizing } \\
\hline & Lipase & \\
\hline \multirow[t]{4}{*}{ Hydrolase } & Pectinase & \multirow[t]{4}{*}{ Scouring } \\
\hline & Protease & \\
\hline & Cellulase & \\
\hline & Cutinase & \\
\hline \multirow[t]{4}{*}{ Oxidoreductase } & Catalase & \multirow[t]{5}{*}{ Bleaching } \\
\hline & Arylesterase & \\
\hline & Glucose oxidase & \\
\hline & Laccase & \\
\hline Hydrolase & Xylanase & \\
\hline Oxidoreductase & Catalase & \multirow[t]{5}{*}{ Dyeing } \\
\hline \multirow[t]{4}{*}{ Hydrolase } & Protease & \\
\hline & Amylase & \\
\hline & Lipase & \\
\hline & Diasterase & \\
\hline Oxidoreductase & Catalase & \multirow[t]{3}{*}{ Finishing } \\
\hline \multirow[b]{2}{*}{ Hydrolase } & Cellulase & \\
\hline & Lipase & \\
\hline
\end{tabular}

Important technological advances in the area of bio-based processing have been recorded in recent times and these have brought important transformations into the production of textiles, which gradually becomes more environmentally conscious (Shen and Smith, 2015; Nimkar, 2018 ). Five important textile applications - desizing, scouring, bleaching, dyeing and finishing - 
are especially noteworthy. However, in our study, we have explored technology experts' views on three major enzyme assisted processes, namely bio-desizing, bio-scouring and bio-bleaching, as they have experienced industrial biotechnological breakthroughs and supersede the efficacy and effectiveness of chemical-based processing for wet textile preparatory processes. Many authors concur that these advanced technologies may have some extensive costs in the initial set-up phase, but in the long term the quantifiable economic gains and the qualitative environmental benefits significantly offset such costs (Verret, 1991; Shen and Smith, 2015; Hack-Polay et al., 2020). This suggests that economics cannot alone guide strategic decision-making.

In the process of desizing, removal of size takes place from woven cotton fabric. Examples of the most common sizes include organic compounds such as starch and its derivatives, cellulosederivatives, polyacrylates and polyvinyl alcohol, etc. They provide protective barriers on yarns during weaving. However, it is essential that the size is removed before dyeing and finishing prior to weaving. In conventional chemical-based textile processing, the fabric is treated with acids, bases or oxidising agents to remove sizes (Aly et al., 2010).

The next key step in wet textile processing is scouring, which involves removal of pectin, waxes, fats and proteinaceous materials, etc., from the outer cuticle and primary walls of cellulosic fibres. Due to poor wettability and a dirty appearance, the non-cellulosic impurities lead to improper dyeing and finishing of the cellulosic fibres. In addition, the presence of waxes in thin outer walls makes primary cell non-cellulosic compounds inaccessible (Hardin, 2010; Madhu and Chakraborty, 2017). As removal of waxes is required for subsequent processing, a hot aqueous alkaline scouring process is employed to eliminate the hydrophobic non-cellulosic components and improve the wettability of the fibre in conventional textile wet processes. Scouring is important as it facilitates uniform dyeing and finishing. However, due to the higher $\mathrm{pH}$ and temperature requirements, alkaline scouring is resource-intensive and does not provide satisfactory wettability. Enzyme mixtures have been able to remove the pectin of cellulosic fibres and improve medium whiteness (Madhu and Chakraborty, 2017). However, the availability of economically viable and commercial enzyme preparations for scouring is below par.

Bleaching is one of the major steps of textile wet processing before cotton dyeing to destroy or decolourise natural pigments present in the fibres (Wang et al., 2007). The natural pigments are usually responsible for the dirty appearance of the fibres after processing (Hussain and Wahab, 2018). Therefore, bleaching is carried out to achieve a pure white appearance before dyeing (El- 
Naggar et al., 2018). In the past, chlorine and oxidising agents were used to treat the fibres in extreme conditions to achieve whitening. Nowadays, hydrogen peroxide is used at an industrial scale under alkaline $\mathrm{pH}$ and near boiling temperatures. Several enzyme-based preparations for bleaching systems with arylesterases and hydrogen peroxide have been found to be effective (Auterinen et al., 2011). This exemplifies the earlier theoretical assumption (Verret, 1991; Cooper, 1993; Shen and Smith, 2015; Hack-Polay, 2020) that the use of advanced technologies in manufacturing presents strategies opportunities and environmental benefits.

In textile wet processing, finishing is the surface modification process for removal of hairlike micro, fuzzy fibrils from the fabric surfaces or yarn, which takes place either before or after dyeing. Bio-finishing/bio-polishing can be achieved by cellulases (Araujo et al., 2008; Saravanan et al., 2009; Choudhury, 2014) and enzymatic treatment on fabric surfaces leads to a softer finish and improved appearance. In textile manufacturing, a ball of fuzz is termed a pill, which poses a serious quality problem due to the unattractive, 'knotty' appearance of the fabric. Bio-polishing prevents pilling and improves colour brightness, hand feel and water absorbance of fibres, and provides a cleaner surface structure (Ibrahim et al., 2011). Traditional approaches use gas singeing for the removal of fuzz and are responsible for the emission of gases from combustion. Enzymatic bio-polishing is considered environmentally friendly due to its ability to replace gas singeing and avoid emissions (Choudhury, 2014). This offers further evidence on the environmental sustainability opportunities offered by enzyme-based processing (Shen and Smith, 2015).

Denim garments are prepared from warp-face cotton fabric in which warp yarn is treated with indigo dyes. In traditional practices, the garments are subjected to a wash treatment by the process of stone-washing to introduce a worn look to them. The strong mechanical abrasive action of pumice stones on fibre surfaces removes dye from the fabric in a non-homogeneous fashion, which ultimately exposes the white interior of the yarn and leads to a faded, worn and aged appearance (Cavaco-Paulo, 1998; Bhat, 2000; Choudhury, 2014). However, denim washing with natural pumice stones can cause severe physical damage to equipment and garments. In addition, the stones produce particulate materials over time and can cause clogging of the machine drainage passage and sewer lines (Pazarlioglu et al., 2005; Yu et al., 2013). Consistent with the scientific literature, there is strong agreement that enzymatic treatments that have replaced stone-washing despite their recentness - are now increasingly used in denim bio-wash because of the environmental sustainability value of this technology (Shen and Smith, 2015). 
Despite the overwhelming research data about such benefits, the introduction of new technologies in textile manufacturing has been slow in emerging markets (Parisi et al., 2015; HackPolay et al., 2020). The main reasons for this slow progress have been linked to economics, cultural issues, training and political inaction (Cooper, 1993; Hack-Polay et al., 2020). These reasons have been applied in a blanket way to all technological sectors in developing countries (Adomako et al., 2019; Kesley, 2009; Ockwell et al., 2015). However, this research seeks to establish whether there are discrete reasons for slow adoption of new technologies in the textile industry in emerging economies. In the textile sector, biotechnologies can have mitigating effects on enzymes and therefore improve quality and at the same time they are more environmentally friendly approaches. The theoretical framework we use (Lewin's Force Field Analysis - explained in the next section) has been chosen to help assess the specificities for the textile industries in emerging market contexts.

\subsection{Theoretical framework}

Lewin's (1951) force field analysis offers an interesting analytical framework for the current research. Lewin argues that in a changing environment, there are critical forces that push organisations to the point where they need to change their processes, direction and operations. However, there are also forces that restrain such moves. The competing forces can alter the organisations' competitiveness if managers do not increase the forces for change and mitigate the restraining forces. In the context of the textile industry, forces for change include environmental degradation, concern for health, lack of clean water and increasing community backlash. At the same time there are opposing forces resisting the change and pressing for the maintenance of the status quo. The opposing forces include economic pressure, training, anxiety about new technologies and job losses. This model enables us to identify the significant issues in changing social phenomena to establish basic constructs that typify them (Thomas, 1985). Figure 1 summarizes our conceptual framework, which is based on an adaptation of Lewin's (1951) Force Field Analysis framework. 


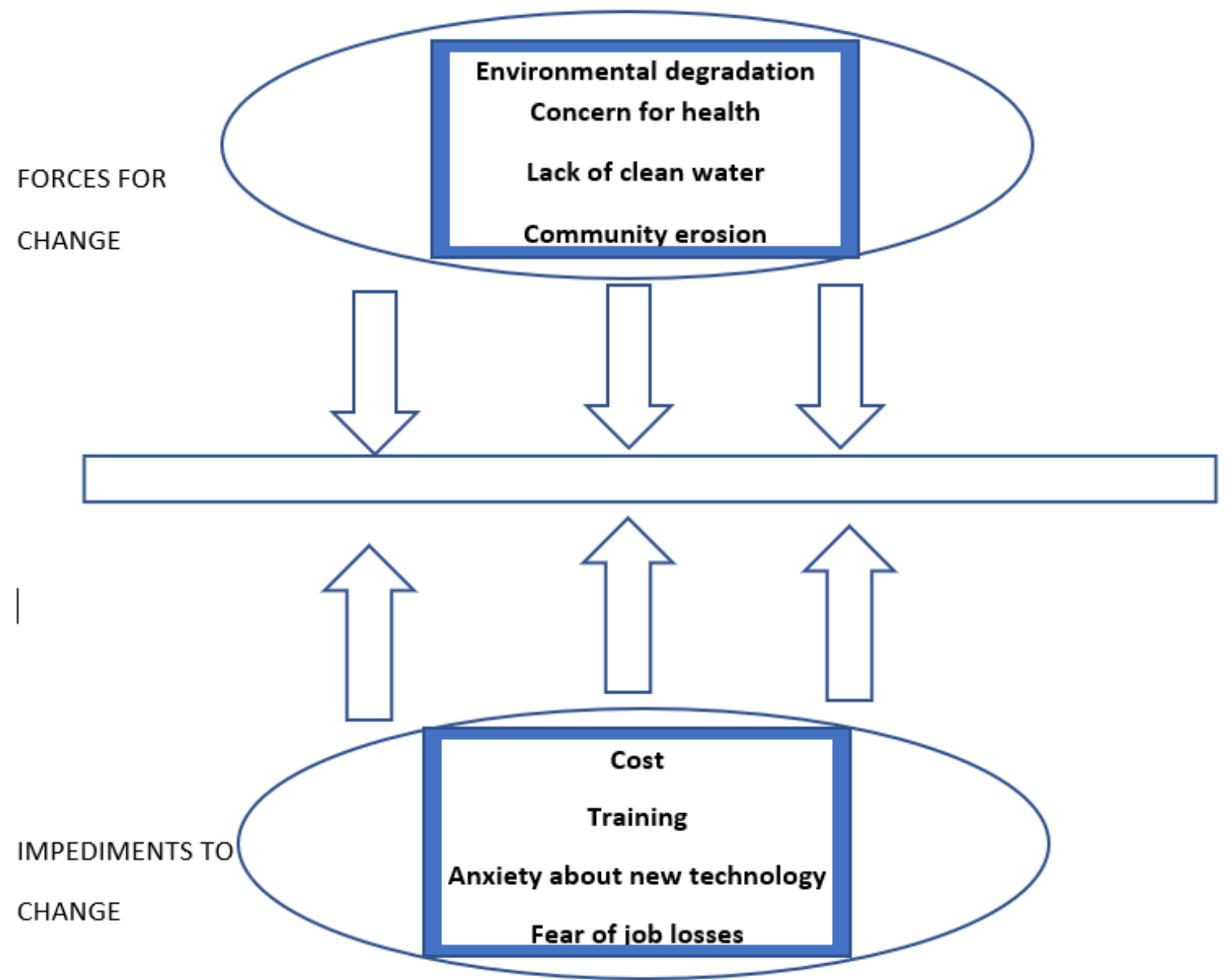

Figure 1: Conceptual framework - an adaptation of Lewin's (1951) Force Field Analysis

Early application of the Force Field Analysis to technology management identified the significance of the framework to the sector (Levi and Lawn, 1993; Capatina et al., 2017). These authors contend that technology adoption is critical to organisational survival in modern organisations, not least because of increased competition but also owing to the fact that consumers are increasingly becoming aware of the environmental and social impacts of technology use. In this perspective, our study bridges the gap in the literature between technological innovation and adoption in developing countries and organisational development theory. The Force Field Analysis framework enables us to evaluate the factors for and against the effective deployment of intellectual and technological capital (UNCTAD, 2014; Capatina et al., 2017). 


\section{Methodology}

We collected semi-structured interviews from three technology experts, 10 industry executives and a key government policymaker. Each technology expert was interviewed on a specific aspect of enzymatic wet textile preparatory processes under the realm of industrial biotechnology we examined in this paper. The industry executives and the policymaker were interviewed in relation to the engagement of industry and government with new textile processing methods that are said to be more environmentally friendly.

We used a snowball sampling technique to reach the participants. According to Atkinson and Flint (2001), snowball sampling is suited for hard-to-reach groups. In this context, it is important to tap into an existing network of qualified research participants via social interaction with the researcher's acquaintances (Faugier and Sargeant, 1997). In the cultural and political contexts of Bangladesh (and many developing countries broadly), the critical issues of connections and trust can stand in the way of reaching suitable participants (Hofstede, 2011; Rahman et al., 2019). We therefore contacted a key scientist in Bangladesh, who then led the research team to another authority in the field and then to a third. The process was repeated to reach the industry executives. The policymaker was the only top official in charge of environmental policy in the field of textile processing. We recognise the limitations of snowball sampling in terms of its potential for bias. We minimised this risk by ensuring that we collected data from participants until we reached saturation, particularly for industry executives. After 10 interviews, the interviews were yielding little new information, prompting the research team to halt the data collection with industry executives. The number of scientists and policymakers used was constrained by the need to have an expert view on discreet enzyme processing methods in the textile sector. Such experts are not numerous.

The interviews were conducted virtually using WhatsApp and Facebook calls. This was the most effective means of reaching the participants, given the spread of their locations at the time of the interviews, e.g. different cities within Bangladesh as well as China and the UK as some industry executives were on business trips at the time. The analysis of the interview data followed three stages. This reflects the work of Guest et al. (2012: 10), who argue that thematic analysis "as in grounded theory and development, requires more involvement and interpretation from the researcher". This signifies the insufficiency of just "counting explicit words or phrases and focusing on identifying and describing both implicit and explicit ideas" (ibid.). The research team 
first transcribed the interviews. Secondly, we manually coded the data. Manual coding was used given the small number of interviews; the researchers could pay greater 'human' attention to the details provided by the participants. Finally, the transcripts were reviewed using the thematic approach to identify recurring themes that would serve for the basis of the discussion of the finding. At this final stage, the research team made connections between identified themes in order to arrive at the final analytical categories.

The research also used the academic literature to further examine technology experts' views about the potency of the use of enzymatic processing for environmental sustainability in the textile industry. The research team has used this approach because, as Dana and Dana (2005) argue, it transcends the traditional hypothetico-deductive framework by allowing the development of a novel cogent perspective. Our team searched the scientific literature using keywords, to identify sources that debate current significant advances in biotechnology, specifically within the textile sector. We then filtered those that more specifically address environmental issues. The limited literature we found enabled the research team to construct the literature review but also crucially to deploy key references to develop a more robust analytical frame. The research team discussed the key findings relating to the benefits and policy, socio-economic and educational questions surrounding the introduction of biotechnologies in textile manufacturing.

\section{Findings}

\subsection{Technology experts' view on the advantages of textile biotechnologies Bio-desizing}

According to our interviewee Technology Expert 1 (TE 1), bio-desizing significantly improves removal of sizes from fabrics and renders more efficient processing in wet textile preparatory processes if compared to conventional desizing processes. He argues that:

"Higher desizing can be achieved with thermo-stable enzymes. This type of enzyme could perform improved swelling of the fabric and lead to increased absorption. The enzymes are isolated from microorganisms living in extreme environments and develop natural ability to adapt under harsh conditions of temperature and $\mathrm{pH}$ to catalyse reactions. They are excellent candidates to serve as better alternatives for industrial applications." 
This perspective is well supported by the technological literature on bio-desizing. It is well documented that amylase enzymes are regarded as the major enzymes for desizing in textile industries and the main application area of amylases in the enzymatic desizing processes or biodesizing (Araujo et al., 2008; Choudhury, 2014). The amylases are categorized based on their biological sources (bacterial, malt and pancreatic) or the degradation mechanism (Madhu and Chakraborty, 2017). The amylases are clustered into two main categories, $\beta$-amylases (saccharogenic) or $\alpha$-amylases (dextrinogenic), depending on the degradation mechanism,

The alpha-amylases act quicker than the $\beta$-amylases. They also show their catalytic activity anywhere on starchy substrates. They are therefore commonly used in textile desizing processes (Regan, 1962; Tzanov et al., 2001; Sojka-Ledakowicz et al., 2006; Hossain and Uddin, 2011; Mojsov, 2011). These enzymes catalyze the hydrolysis of water-insoluble starch to water-soluble end products and can easily be removed from cotton in the subsequent washing steps (Opwis et al., 2010; Shahid et al., 2016).

The desizing process occurs at $70^{\circ} \mathrm{C}$ and above. Commonly, higher temperatures are even more desirable (Shahid et al., 2016). Nonetheless, a standard amylase possesses the temperature prerequisite of $25-55^{\circ} \mathrm{C}$, while medium temperature-range amylases perform optimally at 50 $95^{\circ} \mathrm{C}$. Careful selection of the correct amylases can enable bio-desizing at temperatures that are above $70^{\circ} \mathrm{C}$ (Ando et al., 2002). Thermo-stable amylases must function above $95^{\circ} \mathrm{C}$ to enable uninterrupted pre-treatment in the desizing process (Choudhury, 2014). Amylases lend themselves to alterations in order to engender superior performance.

Further explanation of the data provided in the interview with Technology Expert 1 (TE 1) exemplifies the importance of the use of amylases in bio-desizing, which increases its value. TE 1 believes that:

"Bacterial $\alpha$-amylases have been characterized and modified to achieve desired functionalities. The modified amylases have shown higher heat-stability, can retain activity over [a] broader range of $\mathrm{pH}$, a requirement for industrial scale textile processing and hold excellent promise in the field of desizing."

Supporting this expert view, Bertoldo and Antranikian (2002) and Siddiqui (2015) found that it is important to adopt a cogent selection of microorganisms from cold, mild and extremely hot environments to produce desizing enzyme preparations with appropriate activity. The authors found that high-temperature bacterial amylases are preferred because of their shorter processing 
time. Scientists observed that desizing with low-temperature $\alpha$-amylases $\left(20-60{ }^{\circ} \mathrm{C}\right)$ is often too slow and is more time-consuming than high-temperature amylases $\left(95-100{ }^{\circ} \mathrm{C}\right.$ or higher). Hightemperature amylases can, additionally, be deployed in steam chambers for a fully continuous desizing processing (Shahid et al., 2016). Scientists therefore hypothesise that high-temperature bacterial amylases are likely to be more accepted because the rise in temperatures when desizing can enable the effective elimination of starch and reduce the length of the process (Saravanan et al., 2011).

TE 1 provides a simple guide to using bio-desizing to ensure that practitioners and investors are not fazed by the myth about the application of new biotechnologies. He argues that:

"Often users think that new biotechnologies are over-complicated. This mindset deters them from engaging with these incredibly efficient, healthy and environmentally friendly new ways of approaching textiles."

The expert then elaborates on the simplicity of bio-desizing:

"So, here is a basic explanation about the bio-desizing process. The enzymatic desizing or bio-desizing produces various types of simple sugars as end products. The desizing process has three main stages: impregnation, incubation, and after-wash. A prewash removes non-starch water-soluble additives from the fabric and allows interaction between amylases and starch molecules. Impregnation takes place at temperatures above $70^{\circ} \mathrm{C}$ which is followed by a longer incubation period at a lower temperature. This allows soaking of the fabric with amylase at the optimum temperature. The duration of the incubation period is usually 2-16 hours depending on the stability and the activity of the enzyme relative to the processing temperature and $\mathrm{pH}$, the nature of the size, and fabric. Lastly, the fabrics are washed off above $80^{\circ} \mathrm{C}$ in alkaline liquor followed by neutral liquor."

Choudhury (2014) established an additional value step when he suggested that adding enzymes that are different from amylases, like lipases, can bring about efficient desizing owing to synergistic effects and can remove natural crusts from cellulosic materials. When conducting desizing, beef as well as various fats are included into the size bath for the purpose of boosting the sized yarn's slickness. Lipases can efficiently eliminate the hydrophobic part of the size that derives when fat-based lubricants are added. This is provided that such lubricants are eradicated during the sizing process, as they could be hard to be eliminated otherwise, even by scouring . Enhanced desizing is advantageous because it can shorten the processing time and facilitate higher 
production quality products which are more similar in the way they work (Madhu and Chakraborty, 2017).

TE 1 is optimistic about bio-desizing as he concludes:

"The bio-desizing process overall provides an efficient way of removing earth alkalis and cationic metal particles from cotton fabric and has the potential to improve desizing performance over normal washing or treatment in alkali."

\section{Bio-scouring}

The second key technology explored in the interviews is bio-scouring, which is similar to the bio-desizing that we explored earlier and presents significant benefits according to our interviewee Technology Expert 2 (TE 2). In summarizing the properties of bio-scouring, TE 2 argues:

"The bio-scouring of cotton with enzymes has shown excellent promise as the operation can be carried out over a broader range of $\mathrm{pH}$ and at lower temperatures if compared to conventional scouring with chemicals. Besides, the bio-scouring can be termed an eco-friendly approach as it requires less energy and replaces harmful chemicals which are used in the conventional textile wet processing."

In support of this view, some researchers argue that enzyme-assisted scouring specifically targets non-cellulosic impurity with no alteration to the substrate (Hartzell and You-Lo 1998; Shahid et al., 2016). Consequently, the inherent properties of cotton fibre are not modified; thus, the fabric remains softer even following its processing. Bio-scouring is more suitable for the mixture of cotton with silk, wool and cashmere while the severe alkaline conditions of classic scouring affect these fibres' quality (Csiszar et al., 2001; Sojka-Ledakowicz et al., 2006; Wang et al., 2007; Madhu and Chakraborty, 2017).

TE 2 also emphasised the health benefits of the bio-scouring carried out using pectinase enzymes which essentially removes pectin from cotton fabrics and replaces the application of potentially hazardous chemicals from the textile materials. TE 2 contends that:

"After waxes are removed from the outer wall of cotton, pectin is the major non-cellulosic substance, which acts as [a] cementing or adhesive material between cellulosic and non-cellulosic substances. For this purpose, pectin 
needs to be removed to access and eliminate the non-cellulose part of cotton; hence, the process of bio-scouring is based on the concept of breaking down pectin with the enzymes. The fabrics treated with harmful chemicals for conventional scouring are harmful for human health."

There has been a steady support for the argument that pectinases are effective in bioscouring in contrast with the process that uses other enzymes. Scientists also believe that the initial purpose of attempting bio-scouring with pectinases, proteases and lipases enzymes is to remove non-cellulosic contaminations in the fibre (Shahid et al., 2016; Madhu and Chakraborty, 2017). Scientists established that pectinases were more effective, ahead of lipases; proteases were not found to have a similar degree of effectiveness. Consequently, they have categorised and augmented various forms of pectinases and their mixtures to render cotton fibre scouring more effective.

TE 2 also provides a simple account of the bio-scouring in textile wet preparatory processes:

"The optimum $\mathrm{pH}$ for pectinase action lies in the range of pH 5-9 and the type of pectinase dictates whether [the] pH of the bath should be kept acidic or alkaline. However, both acidic and alkaline pectinases tend to produce similar scouring effects. It is worth mentioning that acidic pectinases work in low concentrations.

This could be explained as an acidic medium could degrade the pectin within the pH range 4-6 without pectinase and facilitate the removal of pectin in this condition. However, bio-scouring was initially pegged back by the longer incubation period. In recent times, the introduction of new pectinase types and incorporation of additives into the bio-scouring processes have led to sustainable industrial processing. In line with these efforts, biotechnological approaches have been employed to produce a novel pectinase for bio-scouring with low dose requirement to work under higher temperature and alkaline conditions. "

The environmental benefits of bio-scouring coupled with bleaching and other subsequent steps are evident even in its basic application. As TE 2 argues:

"Sometimes, scouring and bleaching can be conducted in [a] single step, which uses less energy and water."

\section{Bio-bleaching}

In conventional chemical-based textile wet processing, manufacturers achieve bleaching through hydrogen peroxide at alkaline $\mathrm{pH}$ in near-boiling temperatures. To be specific, the 
bleaching process is conducted in an alkaline bath at $\mathrm{pH} 10-12$ and at temperatures up to $120{ }^{\circ} \mathrm{C}$. As bleaching is conducted at high working temperatures, the process is energy intensive. In addition, various auxiliary chemicals are added into the bath, which increases the total organic carbon (TOC) and chemical oxygen demand (COD) values of effluents (Mojsov, 2015). Another problem is the removal of hydrogen peroxide residues from fabric surfaces, which makes subsequent fabric wet preparatory processes cumbersome. Sometimes, bleaching with peracetic acid (PAA) has been considered as an alternative to bleaching with hydrogen peroxide (Hickman, 2002; Tavčer, 2010). However, a study showed that bleaching with hydrogen peroxide followed by catalase treatment was able to remove hydrogen peroxide residues from the fabrics surface and dyeing of cotton fabrics with a bifunctional reactive dye achieved significant improvements (Amorim et al., 2002; Mojsov, 2015). In concordance to the above results, Technological Expert 3 (TE 3) stresses that bleaching is a key issue when dealing with wet preparatory processing of textiles. For instance, as he states:

"Eliminating the residual hydrogen peroxide in fabrics following bleaching commands significant volumes of water; this is an important problem when undertaking dyeing operations. The radical reactions on the surface of the fabrics diminish the polymerization level, occasioning fibre impairment."

This opinion expressed by TE 3 is congruent with those expressed by numerous experts in the field. Such authors have used alternative bleaching approaches using a mix of enzymes; examples include enzymatic bleaching with laccase or mediator systems, glucose-oxidases, and peroxidases as well as enzymatically in situ-generated peracids. Pereira et al. (2005) and Spicka and Tavcer (2013), for instance, believe that bio-bleaching using laccase or mediator methods shows more effectiveness owing to the precision it has when acting on coloured substances. Other authors, e.g. Couto and Toca-Herrera (2006), Hadzhiyska et al. (2006), Kim et al. (2007) and Gonçalves et al. (2014), found that employing laccases to bleach cotton shows how coloured flavonoids can be affected by enzymes, e.g. removal of their colour or destroying them altogether can occur by alteration of the groups of phenolic hydroxyl.

These significant aspects of bio-bleaching led TE 3 to suggest that the value of biobleaching for the environment should not be understated. He argues that: 
"There are many instances when chemical processes have been complemented with either enzymatic pre- or post-treatment approaches. These coupled processes are sometimes preferable as they lessen the demand for excessive toxic and harsh chemical treatment. For example, short duration laccase-mediated enzymatic pretreatment prior to hydrogen peroxide bleaching improves the whiteness of cotton fabrics and decreases dosage requirement for hydrogen peroxide at lower temperature."

This expert opinion is supported by significant evidence in the scientific literature (see Tzanov et al., 2003; Basto et al., 2007; Abou-Okeil et al., 2010). In particular, Tzanov et al. (2003) found evidence that using the laccase-hydrogen peroxide method together with ultrasound energy was beneficial to cotton bleaching when conditions were kept mild ( $\mathrm{pH} 5$ and $60^{\circ} \mathrm{C}$ for $30 \mathrm{~min}$ ) and the process also augmented quality, providing the desired degree of whiteness. Increased bleaching efficiency with ultrasound energy can be attributed to increased enzyme activity and improved the diffusion of the enzyme to the substrate surface (Basto et al., 2007; Abou-Okeil et al., 2010). Scientists have established that the enzyme glucose oxidase has substantial potential to produce hydrogen peroxide from glucose in the process of bleaching cotton.

Technology Expert 3 (TE 3) hails bio-bleaching biotechnology he believes that there is strong evidence supporting the view that it is environmentally conscious and effective. He observes that:

"This enzymatic system can utilise glucose in both desizing waste baths and scouring treatments, decrease water consumption and discharges less wastewater."

In the past decade, scientists such as Zhou et al. (2012), Hebeish et al. (2013) and Shahid et al. (2016) have reported that single bath desizing and bleaching or bleaching applied using a reused desize bath when used concurrently bring about a greater degree of whiteness and higher mechanical properties like tensile and tear strength. It has been proven that enzyme glucose oxidase produces hydrogen peroxide in mildly acidic to neutral conditions at modest temperatures; however, bleaching necessitates temperatures as high as $80-90^{\circ} \mathrm{C}$ and high alkaline $\mathrm{pH} 11.0$ to arrive at the expected result (Anis et al., 2009; Farooq et al., 2013).

TE 3 is unequivocal that: 
"If newly developed enzymatic processes could be used globally, it is anticipated that it could save approximately 10 trillion litres of freshwater and reduce greenhouse gas emissions to 30 million metric tons annually."

\subsection{Industry and policymaker's perspectives on the impediments to embracing textile processing biotechnologies}

The adoption of technologies in emerging markets is increasing fast. However, this has not been reflected in the textile sector, where biotechnologies have not been widely popularised. Despite the expert technologists' views promoting the viability and the environmental friendliness of innovative biotechnological approaches in textile processing, there is strong resistance amid local actors in the developing world in engaging with these new technologies (Ribeiro and Shapira, 2019). These impediments to change are manifold, as the view of the local actors in the interviews demonstrate. The coding of the data has enabled us to identify three main impediments: policy framework, socioeconomics and education.

\section{Consistent policy framework}

The interview data revealed that a key impediment to the adoption of biotechnologies in the textile industry is the lack of vigorous government action geared at establishing a systematic and consistent policy framework. A reason for this is wariness about the potential cost in terms of government investment in the industry infrastructure. Equally, at the micro-level in the textile manufacturing companies, there is a deficiency in strategic planning and engagement with environmental standards. Industry and political leaders interviewed displayed this absence of systematic approach in their narratives. For instance, they showed reluctance to embrace changes in textile processing methods. The views below highlight this reluctance:

\footnotetext{
"We will continue to operate as we do if the authorities do not oblige us to change. Changing our processing methods will take a lot of resources and could lead to losses." (Industry Executive 5)

"Very few of us are prepared to gamble with new processes till we are sure that they work." (Industry Executive 6)
}

"The government is doing things step by step to resolve problems when they arise. Big long-term plans are not always affordable to our government and can disturb communities." (Policymaker) 
The role of the government has been criticised by some industry executives. For example:

"The government is not strong in terms of leading the change with strong legislation. Some companies like ours are willing to go through the change but if the government does not have a strict policy, while we will be investing money and (possibly) losing it. However, some other companies will use old methods and continue to pollute without consequences. So, we all do the same." (Industry Executive 1)

"It is clear that our company does not meet all the standards set by the government. But now the government doesn't compel the industry to adopt greener methods; as there is no prescriptive legislation, we get away with our old ways" (Industry Executive 4)

It can be seen from the above participant comments that the adoption of biotechnology processing in the textile industry is contingent upon rigorous regulatory frameworks, i.e. political will, strategic thinking, and economic operator engagement. Moving away from chemical-based processing could be problematic if a new industrial structure is not activated. Policymakers recognise this imperative, as shown in the statements below:

"Companies are starting to comply with the limited regulations that we have formulated so far. The government is now looking to develop a coherent environmental policy for the textile sector." (Policymaker)

"The government is deploying the necessary means to deal with environmental issues caused by textile production. Technical schools have been created and are being equipped for that purpose." (Policymaker)

However, industry leaders who are sensitive to environmental issues believe that the officials could do more, particularly to relieve businesses of the initial financial pains deriving from investments in new biotechnologies. The industry leaders thus point to socioeconomic impediments.

\section{Socioeconomics}

From the participants' perspective, economics appears to be a major factor affecting the implementation of biotechnologies in the textile sector in emerging markets. They fear losing their competitive edge, as two of the industry executives contended: 
"We are in business because we can make products that western countries want more cheaply. If we go into expensive technologies, our costs will increase, and we'll have to put prices up. That can take business away from us to China, Pakistan or Sri Lanka." (Industry Executive 1)

"If the government doesn't do anything to cut taxation on imports, we will not be able to afford new technologies." (Industry Executive 2)

The cost of technology and the product used in textile processing is therefore a significant deterrent for the industry in terms of adopting biotechnologies. Many products used in manufacturing in emerging economies are imported and higher tariffs can only hinder the prospect of buying new technologies.

As two of the industry executives interviewed pointed out:

"Local companies have limited abilities to provide finished ingredients and suitable technological products due to lack of expertise, capital, and research \& development funding." (Industry Executive 3).

"Adopting biotechnologies in textile processing in this country is a very important economic endeavour. This also has psychological and institutional implications." (Industry Executive 6)

The unanimous view among industry executives and policymakers is that, in order to achieve quicker transformation of the textile industrial landscape, a combination of policy framework and financial incentives are required simultaneously. Industry Executive 4's words typify this unanimous view:

"Most textile operators are conscious that we should improve. We can see sometimes the effect that our plants have on the community. But many of us are in denial because of our own financial interests. We are capable of adopting new methods if we are compelled to and are given some financial incentives life subsidies." (Industry Executive 4)

In total, the shortage of institutional frameworks and economic incentives means that industry operators fail to see the wider range of opportunities, including the global push for greener 
commodities. Their main argument, and that of the government itself, for resisting the introduction of biotechnologies centres on economics and short-term gains.

\section{Education}

An important barrier to the introduction of biotechnologies in emerging economies is education and reliable information. As industry executives argued earlier, textile operators are increasingly becoming aware of the prominence of environmental issues, but this basic awareness is not always reinforced with systematic educational efforts. Industry Executive 8 believes:

"There are deficient informational and educational systems to help investors, particularly older operators, understand more deeply the benefits of new technologies and the fact that environmental degradation might not be reparable. Many investors did not attend higher education or do not know much about chemicals."

As a result of the lack of education, most investors are not proactive in tackling environmental issues through the search for new methods. This perspective is widely held by the industry leaders, as per the following comments:

"People need to be educated about alternatives to current harmful chemicals used in textile processing to protect the health and livelihood of our communities." (Industry Executive 5)

"Operators and employees simply lack training and knowledge in the area. If they did, they'd also have greater awareness of the dangers of traditional chemical processing in textiles and how the waters are being polluted through that." (Industry 8)

The use of biotechnologies in textile processing could appear to be convoluted. However, without systematic informational and technical support, the move from traditional processing to new applications could be troublesome. Many participants concurred and positioned the lack of training and skills as one of the most significant impediments to biotechnological processing in the textile sector. Further support of the educational argument is provided by two more of the industry executives interviewed: 
"The country has limited skilled labour that is capable of understanding and operating new and cutting-edge biotechnology. Many of our universities do not have the facilities to train such [a] high-skilled technical labour force. And sending the students to western countries is extremely costly." (Industry Executive 2)

"The lack of skills nationally means that many of the ingredients for manufacturing in textile is made abroad. we had the technical expertise to make the yearn that we currently import, the industry could be heading the right direction - the direction of self-sufficiency." (Industry Executive 7)

Many companies in the textile sector have no staff who possess sufficient scientific and technical knowhow, which means that the companies and the emerging countries themselves lack dynamic capabilities. Industry Executive 4 asserted:

"We want to train our employees to gain higher skills. But with the lack of local experts, we hire consultants, usually foreigners. But this is expensive. So, training provision is not as regular as it should be." (Industry Executive 4)

Industry Executive 10 made plain a significant thought that has been latent in many of the other participants' accounts: this is the issue of academic and scientific research. He argues that:

"Universities here do not conduct enough research to support the textile sector. Everybody criticizes us that we are polluting the environment. But very few help us find solution through research." (Industry Executive 10)

\section{Discussion and conclusions}

The study sought to examine two main research questions: To what extent can the use of industrial biotechnology, and particularly enzyme-based processing, bring about greener alternatives in textile industries? Why do economic and political actors in developing countries resist the adoption of innovative enzymatic biotechnology in textile manufacturing? The findings revealed that the implementation of enzymatic textile processing technologies leads not only to direct benefits to the environment but also to economic development in the long run. Conventional textile processing uses many hazardous materials, causing major damage to water resources in addition to being highly energy intensive; this has led consumers across the globe to demand that textile processors adopt greener, gentler and safer production technology. But this push by 
customers has been slow in the developing world. Consumers identify with and prefer brands which address their sustainability desires and employ ethical working practices. Biotechnological approaches in textile processing could help the textiles industries to move towards long-term sustainability, using renewable enzyme products and environmentally progressive processes (Jørgensen et al., 2006; Shen and Smith, 2015).

Biotechnologies have been remarkably accepted in diverse sectors owing to their substrate specificity and green chemistry. Employing enzymes specifically for textile processing is acknowledged because of their ability to replace the harsh chemicals used conventionally and to conserve water and energy (Rahman et al., 2019). This reinforces Levi and Lawn's (1993) view that identifying the driving and restraining forces that impact on technological innovation can yield significant benefits for organisations. However, the high cost and lack of long-term stability under storage and process conditions have often hampered their application.

Bio-agents and materials can help significantly in halting the worsening of such environmental conditions and in improving the parameters in the future, which may eventually lead to green industrial transformation there. Incorporation of biotechnology in the textile and garment industry in developing countries is an economic, psychic, management capability and formal institutional issue. Competitiveness of developing countries' textile and garment industry in the world market lies mainly in their cheaper cost, which they want to retain in any circumstances. A key contribution of our research is to establish that weak formal institutional governance structures in the developing countries either keep their eyes shut to the powerful industry and, thus, do not make them comply with good environmental practices, or are incapable of monitoring and enforcing. Many textile entrepreneurs suffer from the myopic vision of enterprise growth based on 'low cost at any expense', while they fail to see the growth of demand for 'green textiles and garments' in the premium markets (Hack-Polay et al., 2020). The other probable issue is the limited technological and management capability to turn an enterprise into a 'green enterprise' through shifting to bio agent and chemical-based textile and garment production and manufacturing. Developing countries source their 'not green technology' supplies mainly from other advanced developing countries like China and India. Industrialized nations have developed 'green chemical and technology' suppliers who can effectively contribute to the greening of textile and garment industries in the least developing and developing countries. The fact that the supplying developing countries may themselves have quality assurance issues means that these 
issues get cascaded to the client developing countries, making environmental sustainability more problematic (Li-Hua and Khalil, 2006; UNCTAD, 2014).

\section{Implications}

There is a need to create incentives for textile producers to invest both time and financial resources to introduce new technology in the industry to ensure that they do not suffer economic losses as a result of embracing environmentally sustainable technologies (Amankwah-Amoah, 2015). In addition, textile processing industries require a new production line set-up to replace existing ones for introducing enzyme-assisted processes, which involve significant investment, as explained by half of the participants in the study. The processing usually takes place in wellestablished industrial settings in which chemical processes are strictly defined and well controlled within the production chain (Amankwah-Amoah, 2019). However, the economic restrictions could be overcome, and integration of enzyme technology is possible if the enzymatic processes supersede chemical methods as inexpensive, and replacement of technology does not incur any sunk cost.

As per our conceptual framework based on Lewin's (1951) Force Field Analysis of change, the forces impeding change in the textile industry in developing countries can be weakened to create conditions for introduction of environment-friendly biotechnologies. The formulated regulatory frameworks in emerging markets are not sufficiently elaborate and cannot ensure sustainable environment protection (UNCTAD, 2014). Hence, it is necessary to establish the policy framework, and educational and financial investment to enable faster adoption of technologies. The theoretical contribution of the paper is also situated in the extension of the literature on the weight of technology in modern society and contemporary workplaces (Perria, Giglioa and Corvelloa, 2020; Antoniou and Ansoff, 2004; Sengupta, Mohr and Slater, 2006). Our study clearly postulates that technology presents strategic opportunities for organisations that source it and deploy it effectively. Our research also extends the literature on the cultural barriers to technology adoption (Lee, Trimi and Kim, 2013).

\section{Limitations and further research}

We acknowledge the limitations of this research in terms of the small sample size and the fact that the data has been collected in a single country. This poses a problem not just in terms of validity, but also in terms of generalisability. Future research could use a larger sample and 
probability sample to ensure greater validity and generalisability of the finding. This could be further enhanced with a degree of comparison between developing countries that host significant textile industries. Additionally, a critical focus on the cultural aspects - particularly using Hofstede's (2011) cultural dimensions - will elucidate differences among developing countries with regards to cultural enablers and barriers. Hofstede found that countries exhibited varying levels of Masculinity/Femininity, Collectivism/Individualism, Uncertainty Avoidance (UAI) and Long-Term Orientation (LTO). Examining these dimensions in a study of technology adoption in the textile sector in various developing countries would enable educational and economic actions to steer greater awareness of the benefits of technology for environmental sustainability.

\section{Acknowledgement}

The work is funded by the Commonwealth Rutherford Fellowship (BDRF-2017-28) 


\section{References}

Abou-Okeil, A., El-Shafie, A., and El-Zawahry, M.M. (2010). Eco-friendly laccase hydrogen peroxide/ultrasound-assisted bleaching of linen fabrics and its influence on dyeing efficiency. Ultra. Sono., 17, 383-390.

Adomako, S., Gasor, G. K., \& Danso, A. (2013). Examining human resource managers' involvement in mergers and acquisitions (M\&As) process in Ghana. J. of Man Pol \& Prac, 14(6), 25-36.

Adomako, S., Amankwah-Amoah, J., \& Danso, A. (2019). The effects of stakeholder integration on firm-level product innovativeness: insights from small and medium-sized enterprises in Ghana. $R \& D$ Man, 49(5), 734-747.

Aly, A.S., Sayed, S.H.M., and Zahran, M.K. (2010). One-step process for enzymatic desizing and bioscouring of cotton fabrics. J. Nat. Fib., 7, 71-92.

Amankwah-Amoah, J. (2015). Explaining declining industries in developing countries: The case of textiles and apparel in Ghana. Com. \& Chan., 19(1), 19-35.

Amankwah-Amoah, J. (2019). Technological revolution, sustainability, and development in Africa: Overview, emerging issues, and challenges. Sust. Devel., 27(5), 910-922.

Amorim, A. M., Gasques, M. D. G., Jürgen, A., and Scharf, M. (2002). The application of catalase for the elimination of hydrogen peroxide residues after bleaching of cotton fabrics. An. Acad. Bras. Ciên., 74, 433-436.

Ando, S., Ishida, H., Kosugi, Y., and Ishikawa, K. (2002). Hyperthermostable endoglucanase from Pyrococcus horikoshii. App. Environ. Micro., 68, 430-433.

Antoniou, P. H. and Ansoff, H. I. (2004). Strategic management of technology. Tech. Ana. \& Str. Man., 16:2, 275-291

Anis, P., Davulcu, A., and Eren, H.A. (2009). Enzymatic pre-treatment of cotton Part 2: peroxide generation in desizing liquor and bleaching. Fib. Text. East. Eur.17, 87-90.

Araujo, R., Casal, M., and Cavaco-Paulo, A. (2008). Application of enzymes for textile fibres processing. Bio. \& Biotrans., 26, 332-349.

Atkinson, R. \& Flint, J. (2001). Accessing hidden and hard-to-reach populations: Snowball research strategies. Soc. Res. Upd., 33.

Auterinen, A.L., Prozzo, B., Redling, E., Vermeersch, L. and Yoon, M.Y., Danisco US Inc, 2012. Enzymatic textile bleaching compositions and methods of use thereof. U.S. Patent App. $13 / 063,140$.

Basto, C., Tzanov, T., and Cavaco-Paulo, A. (2007). Combined ultrasound-laccase assisted bleaching of cotton. Ultra. Sono., 14,350-354.

Bertoldo, C., and Antranikian G. (2002). Starch-hydrolyzing enzymes from thermophilic archaea and bacteria. Cur. Opin.Chem. Biol., 6, 151-160. 
Bhat, M.K. (2000). Cellulases and related enzymes in biotechnology. Bio. Advan., 18, 355-383.

Bigliardi, B., Nosella, A., \& Verbano, C. (2005). Business models in Italian biotechnology industry: a quantitative analysis. Techno., 25(11), 1299-1306.

Capatina, A., Bleoju, G., Matos, F., \& Vairinhos, V. (2017). Leveraging intellectual capital through Lewin's Force Field Analysis: The case of software development companies. J. Innov. \& Know., 2(3), 125-133.

Cavaco-Paulo, A. (1998). Mechanism of cellulase action in textile processes. Carbo. Poly., 37, 273-277.

Cavaco-Paulo, A. (2003). Catalysis and processing. In: Cavaco-Paulo, A. and Gubitz, G.M. (ed.), Textile processing with Enzymes. England: Wood. Pub. Ltd. pp. 86-116.

Chatha, S. A. S., Asgher, M., \& Iqbal, H. M. (2017). Enzyme-based solutions for textile processing and dye contaminant biodegradation—a review. Env. Sci. Pollu. Res., 24(16), 14005-14018.

Choudhury, A.K.R. (2014). Sustainable textile wet processing: Applications of enzymes. In: Muthu, S.S., (ed.) Roadmap to Sustainable Textiles and Clothing. Singapore: Springer. pp. 203238.

Coccia, M. (2017). The source and nature of general purpose technologies for supporting next Kwaves: Global leadership and the case study of the US Navy's mobile user objective system. Tech. Fore. \& Soc. Chan., 116, 331-339.

Cooper, P. (1993). Removing colour from dyehouse waste waters - a critical review of technology available. J. Soc. Dye. Col., 109(3) 97-103

Couto, S.R. and Toca-Herrera, J.L., 2006. Lacasses in the textile industry. Bio. Mol. Bio. Rev, 1,115-120.

Csiszár, E., Losonczi, A., Szakács, G., Rusznák, I., Bezúr, L. and Reicher, J., (2001). Enzymes and chelating agent in cotton pretreatment. J. Bio., 89, 271-279.

Dana, L.P. \& Dana, T.E. (2005). Expanding the scope of methodologies used in entrepreneurship research. Int. J. Ent. \& Smal. Bus., 2(1), 79-88.

Danso, A., Adomako, S., Amankwah-Amoah, J., Owusu-Agyei, S., \& Konadu, R. (2019). Environmental sustainability orientation, competitive strategy and financial performance. Bus Strat \& the Env, 28(5), 885-895.

Deng, H., Hu, R., Pray, C., \& Jin, Y. (2019). Impact of government policies on private R\&D investment in agricultural biotechnology: Evidence from chemical and pesticide firms in China. Tec. For. \& Soc. Chan., 147, 208-215.

El-Naggar, A., Shaheen, S. M., Ok, Y. S., \& Rinklebe, J. (2018). Biochar affects the dissolved and colloidal concentrations of $\mathrm{Cd}, \mathrm{Cu}, \mathrm{Ni}$, and $\mathrm{Zn}$ and their phytoavailability and potential mobility in a mining soil under dynamic redox-conditions. Sci. Tot. Env., 624, 1059-1071. 
Enslev, L., Mirsal, L. and Winthereik, B.R., (2018). Anticipatory infrastructural practices: The coming of electricity in rural Kenya. Ener. Res. \& Soc. Sci., 44, 130-137

Farooq, A., Ali, S., Abbas, N., Fatima, G.A. and Ashraf, M.A. (2013). Comparative performance evaluation of conventional bleaching and enzymatic bleaching with glucose oxidase on knitted cotton fabric. J. Clean. Prod., 42, 167-171.

Faugier, J. \& Sargeant, M. (1997). Sampling hard-to-reach populations. J. Advan. Nur., 26, 790797.

Gonçalves, I., Herrero-Yniesta, V., Arce, I.P., Castañeda, M.E., Cavaco-Paulo, A., and Silva, C. (2014). Ultrasonic pilot-scale reactor for enzymatic bleaching of cotton fabrics. Ultra. Sono., $21,1535-1543$.

Guest, G., MacQueen, K. M., \& Namey, E. E. (2012). Introduction to applied thematic analysis. App. Them. Anal., 3, 20.

Gwozdz, W., Steensen Nielsen, K., and Müller, T. (2017). An Environmental Perspective on Clothing Consumption: Consumer Segments and Their Behavioural Patterns. Sust., 9, 762-789.

Hack-Polay, D., Rahman, M., Billah, MD M. and Al-Sabbahy, H. (2020). Big data analytics and sustainable textile manufacturing: decision-making about the applications of biotechnologies in developing countries. Man. Dec.. ISSN 0025-1747

Hadzhiyska, H., Calafell, M., Gibert, J.M., Dagà, J.M. and Tzanov, T., (2006). Laccase assisted dyeing of cotton. Bio. Let., 28, 755-759.

Hardin, I.R. (2010). Enzymatic treatment versus conventional chemical processing of cotton. In Nierstrasz, V. A. and Cavaco-Paulo, A. (eds.), Advances in Textile Biotechnology, Cambridge, UK: Wood. Pub. Ltd. pp. 132-149.

Hartzell, M.M., and You-Lo, H. (1998). Pectin-Degrading Enzymes for Scouring Cotton. In Eriksson K.-E.L. and Cavaco-Paulo, A. (eds.), Enzyme Applications in Fiber Processing, Ame. Che. Soc., 687. pp. 212-227.

Hebeish, A., Hashem, M., Shaker, N., Ramadan, M., El-Sadek, B. and Hady, M.A., (2013). New development for combined bioscouring and bleaching of cotton-based fabrics. Res. J. Tex. \& App., 17, 94-103.

Hickman, W. S. (2002). Peracetic acid and its use in fiber bleaching. Rev. Prog. Col. \& Rel. Top., 32, 13-27.

Hofstede, G. (2011). Dimensionalizing Cultures: The Hofstede Model in Context. Online Readings in Psy \& Cul, 2(1).

Hossain, S., and Uddin, K. (2011). Comparative analysis between conventional pretreatment and bio-preparation. Int. J. Eng. \& Tech., 11, 16-21.

Hussain, T., and Wahab, A. (2018). A critical review of the current water conservation practices in textile wet processing. J. Clean, Prod., 198, 806-819. 
Ibrahim, N. A., El-Badry, K., Eid, B. M. and Hassan, T. M., (2011). A new approach for biofinishing of cellulose-containing fabrics using acid cellulases. Carb. Poly., 8, 116-121.

Jørgensen, M.S., Andersen, M.M., Hansen, A., Wenzel, H., Thoning, T., Pedersen, U.J., Falch, M., Rasmussen, B., Olsen, S.I. and Willum, O.,(2006). Green technology foresight about environmentally friendly products and materials- challenges from nanotechnology, biotechnology and ICT. Dan. Env. Prot. Agen. Work. Rep., 34.

Kelsey, J. B. (2013). Constraints on the adoption of agricultural technologies in developing countries. Literature review, Agri. Tech. Adop. Ini., J-PAL (MIT) and CEGA (UC Berkeley), https://escholarship.org/content/qt6m25r19c/qt6m25r19c.pdf, accessed 17/05/2020

Kim, S., Moldes, D., and Cavaco-Paulo, A. (2007). Laccase for enzymatic colouration of unbleached cotton. Enz. \& Micro. Tech., 40, 1788-1793.

Konde, V. (2009). Secrets to developing a successful biotechnology industry: lessons from developing countries. Asia. Bio. \& Dev. Rev., 11, 11-33.

Lee, S-G, Trimi, S. and Kim, C. (2013). The impact of cultural differences on technology adoption. J. Worl. Bus. 48(1) 20-29.

Levi, D. and Lawn, M. (1993). The driving and restraining forces which affect technological innovation in organizations. J. Hig. Tech. Man. Res., 4(2) 225-240

Lewin, K. (1951). Field Theory in Social Science. Harper and Row: New York.Li, M., and Hinks, D. (2012) An Environmentally Benign Approach to Cotton Preparation: One Bath Enzymatic Desizing, Scouring \& Activated Bleaching. AATCC Review, 12, 46-51.

Li, S., Yang, X., Yang, S., Zhu, M. and Wang, X., (2012). Technology prospecting on enzymes: Application, marketing and engineering. Comp. \& Struc. Bio. J., 2, e201209017.

Li-Hua, R. and Khalil, T. (2006). Technology management in China: a global perspective and challenging issues. J. Tec. Man. Chin., 1(1) 9-26.

Madhu, A., and Chakraborty, J.N. (2017). Developments in application of enzymes for textile processing. J. Clean. Prod., 145, 114-133.

Mojsov, K. (2011). Application of enzymes in the Textile industry; a review. In: II International Congress 'Engineering, Ecology and Materials in the Processing Industry', 9th-11th March, Jahorina, Bosnia and Herzegovina. pp. 230-239.

Mojsov, K. (2015). Bioscouring and bleaching process of cotton fabrics - an opportunity of saving water and energy, J. Text. Inst., 107, 905-911.

Nimkar, U. (2018). Sustainable chemistry: a solution to the textile industry in a developing world. Cur. Opin. Gre. \& Sust. Chem., 9, 13-17.

Ockwell, D., Sagar, A. \& de Coninck, H. (2015). Collaborative research and development (R\&D) for climate technology transfer and uptake in developing countries: towards a needs driven approach. Clim. Cha.,131, 401-415. 
OECD (2001). The application of biotechnology to industrial sustainability-a Primer. Org. Econ. Co-op. Dev. (OECD).

Opwis, K., Mayer-Gall, T., Schollmeyer, E., Dammer, C., Titscher, T., Nickisch-Hartfiel, A., Grün, O., Spurk, C., Schloderer, C., Köppe, A. and Dörfler, C., (2010). Generation of methane from textile desizing liquors. Eng. Lif. Scien., 10, 293-296.

Parisi, M.L., Fatarella, E., Spinelli, D., Pogni, R. and Basosi, R., (2015). Environmental impact assessment of an eco-efficient production for coloured textiles. J. Clean. Prod., 108(A) 514524 ,

Pazarlioglu, N.K., Sariisik, M., and Telefoncu, A. (2005). Treating denim fabrics with immobilized commercial Cellulases. Pro. Bio., 40, 767-771.

Pereira, L., Bastos, C., Tzanov, T., Cavaco-Paulo, A., and Guebitz, G.M. (2005). Environmentally friendly bleaching of cotton using laccases. Env. Chem. Let., 3, 66-69.

Perria, C., Giglioa, C. and Corvelloa, V. (2020). Smart users for smart technologies: Investigating the intention to adopt smart energy consumption behaviors. Tech.Fore. \& Soc. Chan. 155(2020) 119991.

Petruzzelli, A.M., Rotolo, D., and Albino, V. (2015). Determinants of patent citations in biotechnology: An analysis of patent influence across the industrial and organizational boundaries. Tech. For. \& Soc. Chan., 91, 208-221.

Rahman, M., Billah, Md \& Hack-Polay, D. (2019). What is hindering change? Anticipating the barriers to the adoption of enzyme-based textile processing in a developing Country. Bus. Strat. \& Dev. 2, 137-147

Rahman, M., Hack-Polay, D., Billah, M. M., and Un Nabi, M. N. (2020). Bio-based textile processing through the application of enzymes for environmental sustainability. Int. J. Tech. Man. \& Sust. Dev., 19(1), 87-106.

Regan, I., (1962). Enzymes and their application in textile processing, especially desizing. J. Soc. Dye. Col., 78, 533-542.

Ribeiro, B., \& Shapira, P. (2019). Anticipating governance challenges in synthetic biology: Insights from biosynthetic menthol. Tech. For. \& Soc. Chan., 139, 311-320.

Saravanan, D., Prakash, A.A., Jagadeeshwaran, D., Nalankilli, G., Ramachandran, T. and Prabakaran, C. (2011). Optimization of thermophile Bacillus licheniformis $\alpha$-amylase desizing of cotton fabrics. Ind. J. Fib. \& Tex. Res., 36, 253-258.

Saravanan, D., Vasanthi, N.S., and Ramachandran, T. (2009). A review on influential behaviour of biopolishing on dyeability and certain physico-mechanical properties of cotton fabrics. Car. Poly., 76, 1-7.

Sengupta, S., Mohr, J. and Slater, S. (2006). Strategic opportunities at the intersection of globalization, technology and lifestyles. Hand. Bus. Str., 7(1), 43-50. 
Shahid, M., Mohammad, F., Chen, G., Tang, R.C. and Xing, T., (2016). Enzymatic processing of natural fibres: white biotechnology for sustainable development. Gre. Chem., 18, 2256-2281.

Shen, J. (2009). Wool finishing and the development of novel finishes. In: Johnson, N.A.G. and Russell, I.M. (ed.) Advances in wool technology. Cambridge, UK: Wood. Pub. Ltd. pp. 171192.

Shen, J., and Smith, E. (2015). Enzymatic treatments for sustainable textile processing. In: Blackburn, R. (ed.) Sustainable Apparel: Production, Processing and Recycling. Cambridge, UK: Wood. Pub. Ltd. pp. 119-134.

Siddiqui, A.S. (2015). Some like it hot, some like it cold: Temperature dependent biotechnological applications and improvements in extremophilic enzymes. Bio. Adv., 33, 1912-1922.

Sojka-Ledakowicz, J., Joanna, L., and Pyc, R. (2006). Integrated enzymatic pre-treatment of cotton fabrics. J. Nat. Fib., 3, 199-207.

Spicka, N., and Tavcer, P.F. (2013). New combined bio-scouring and bio-bleaching process of cotton fabrics. Mat. \& Tech., 47, 409-412.

Stucki, T., \& Woerter, M. (2019). The private returns to knowledge: A comparison of ICT, biotechnologies, nanotechnologies, and green technologies. Tech. Fore. \& Soc. Chan., 145, $62-81$.

Tavčer, P. F. (2010). Impregnation and exhaustion bleaching of cotton with peracetic acid. Text. Res. J., 80, 3-11.

Thomas, J. (1985). Force Field Analysis: A New Way to Evaluate Your Strategy. Lon. Ran. Plan., $18,54-59$.

Tzanov, T., Basto, C., Gübitz, G.M. and Cavaco-Paulo, A. (2003). Laccases to improve the whiteness in a conventional bleaching of cotton. Macro. Mat. \& Eng., 288, 807-810.

Tzanov, T., Costa, S., Guebitz, G.M. and Cavaco-Paulo, A. (2001). Dyeing in catalase treated bleaching baths. Col. Tech., 117, 1-5.

UNCED (1992). Agenda 21: Chapter 16 Environmentally Sound Management of Biotechnology, 1992 Earth Summit, UN Conf. Env. \& Dev., 16.1-16.46.

UNCTAD (2014). Transfer of Technology and knowledge sharing for development Science, technology and innovation issues for developing countries. Geneva: U. N. Pub.

Verret, R. (1991). Technological Developments in the Textile Industry. J. Text. Inst., 82(2) 129136.

Wang, Q., Fan, X., Hua, Z., Gao, W. and Chen, J., (2007). Influence of combined enzymatic treatment on one-bath scouring of cotton knitted fabrics. Bio. \& Biotran., 25, 9-15. 
Yu, Y., Yuan, J., Wang, Q., Fan, X., Ni, X., Wang, P. and Cui, L., (2013). Cellulase immobilization onto the reversibly soluble methacrylate copolymer for denim washing. Car. Poly., 95, 675680 .

Yusuf, M., Shabbir, M., \& Mohammad, F. (2017). Natural colorants: Historical, processing and sustainable prospects. Nat. Prod. \& Bio., 7(1), 123-145.

Zhou, C., Li, M., Garcia, R., Crawford, A., Beck, K., Hinks, D., \& Griffis, D. P. (2012). Time-offlight-secondary ion mass spectrometry method development for high-sensitivity analysis of acid dyes in nylon fibers. Anal. Chem., 84, 10085-10090. 